\title{
The 'Corbyn Phenomenon': Media Representations of Authentic Leadership and the Discourse of Ethics Versus Effectiveness
}

\author{
Marian Iszatt-White ${ }^{1} \cdot$ Andrea Whittle $^{2} \cdot$ Gyuzel Gadelshina $^{3} \cdot$ Frank Mueller $^{2}$
}

Received: 17 October 2017 / Accepted: 7 March 2018 / Published online: 15 March 2018

(c) The Author(s) 2018

\begin{abstract}
Whilst the academic literature on leadership has identified authenticity as an important leadership attribute, few studies have examined how authentic leadership is evaluated in naturally occurring discourse. This article explores how authentic leadership was characterised and evaluated in the discourse of the British press during the 2015 Labour Party leadership election-won, against the odds, by veteran left-winger Jeremy Corbyn. Using membership categorisation analysis, we show that the media discourse about authentic leadership was both ambiguous and ambivalent. In their representation of authentic leadership, we found that a discourse of 'ethical' leadership was played out in tension with a discourse of 'effective' leadership. We propose that this complex and contradictory discursive landscape is also relevant in business contexts where 'ethical' leaders are subjected to praise for their virtues but also criticism for their ineffectiveness. Future research could usefully study how 'ethical' leaders in different settings can be subject to competing evaluations when their ethical values are discursively contrasted to expectations concerning what it takes to be an 'effective' leader.
\end{abstract}

Keywords Authentic leadership · Ethical leadership · Effectiveness · Media discourse $\cdot$ Membership categorisation analysis $\cdot$ Political leaders $\cdot$ Jeremy Corbyn $\cdot$ British Labour Party

The slogan emblazoned across envelopes containing Jeremy Corbyn's election material, delivered to thousands of Labour members in recent weeks said: 'Warning: contains a new kind of politics'. It was Corbyn's pitch to his party: a new type of politics; bold, authentic and principled. (Observer, 13/09/2015)
Marian Iszatt-White

M.Iszattwhite@lancaster.ac.uk

Andrea Whittle

Andrea.Whittle@newcastle.ac.uk

Gyuzel Gadelshina

Gyuzel.Gadelshina@northumbria.ac.uk

Frank Mueller

Frank.Mueller@newcastle.ac.uk

1 Department of Leadership and Management, Lancaster University Management School, Lancaster LA1 4YX, UK

2 Newcastle University Business School, Newcastle upon Tyne, UK

3 Northumbria University, Newcastle Business School, Newcastle upon Tyne, UK

\section{Introduction}

While the ethics of leadership has a long history, the more recent emergence of a body of literature on authentic leadership has represented a turning point in the discussion of ethics in contemporary leadership studies. In the early authentic leadership literature, authentic leaders are described as those who promote a "positive ethical climate" and are driven by an "internalised moral perspective" (Walumbwa et al. 2008: 94). Within the construct's positive psychology roots, authentic leaders are thought to have a clear sense of their ethical values and a "moral compass" (Ford and Harding 2011: 465) that leads them to act transparently and enact their values in their leadership behaviour (Luthans and Avolio 2003). In other words, authentic leaders are understood to know 'right' from 'wrong' and remain steadfastly 'true to themselves' when putting these values into practice.

Set against this scholarship, this study explores an interesting puzzle drawn from the British press coverage of Jeremy Corbyn, a Labour MP, during the 4-month Labour 
Party leadership election in 2015. During the leadership campaign, Corbyn was singled out as an exemplar of 'authentic leadership': someone with a strong sense of morality who authentically enacts those moral values in his work. However, Corbyn was also subject to a stream of critical coverage in the press that straddled the political spectrum. This criticism was not only directed at his policies but also at his leadership capabilities, targeting his inability or ineffectiveness as a potential leader of the party and possible future leader of the country. The puzzle addressed in this article is therefore as follows: how could an 'authentic leader', with the positive moral connotations frequently attached to this category in the existing literature and in ordinary life, also be subject to such persistent criticism? What could possibly be 'wrong' or 'bad' about being an authentically ethical leader?

To answer this question, we turn to the analysis of naturally occurring discourse. As Pfeffer (1977) noted long ago, leadership is an attribution: something attributed to individuals categorised as leaders to account for organizational outcomes and, more importantly for this article, something attributed to candidates for leadership positions through judgements of their suitability. Actors socially construct the kind of personal attributes associated with the category 'leader' through everyday talk and text about the kinds of person deemed suitable (or unsuitable) for leadership roles (Alvesson and Sveningsson 2003; Fairhurst and Grant 2010; Ford 2006). While Corbyn was almost universally recognised as an 'authentic' leader with a strong ethical position, we reveal the discursive devices through which the press also questioned his suitability as leader of the Labour Party and as a potential future Prime Minister. Through studying media discourse, this article contributes to the existing literature by showing how the ethical dimension of authentic leadership is characterised and evaluated in discourse and by exploring what this means for the practice of authentic leadership in both business and political contexts.

In relation to senior leaders in particular, the media has a significant role to play in shaping the leadership attributions made by followers and other stakeholders. As noted by Mazzoleni and Shultz (1999: 250), the true power of the media lies in the fact that they "construct the public sphere of information" by engaging in the framing of political events, thereby influencing the setting of political agendas. As evidenced by previous studies (Grover and Hasel 2015; Hannah and Zatzick 2008), national politics is a particularly fruitful place for observing this process of attributional shaping because of the wealth of coverage political leaders receive, but the implications of this process of social construction apply to business leaders too. As Grover and Hasel (2015) demonstrate in their study of how leaders recover (or not) from publicised sex scandals, whilst some political leaders have been shown to survive this kind of media coverage, all six of the corporate CEOs in their study were forced to resign.

This article builds on the wider body of social constructionist approaches to studying leadership (Chen and Meindl 1991; Fairhurst and Grant 2010; Meindl 1995) and in particular advances work exploring media representations of leadership (Mavin et al. 2010; Campus 2013). The notion of representation is an important one here: and one in which, as Coleman (2003: 751) observes, "politics has become more like a game ... and games have become more like politics." Thus "[h]ow people look at [reality TV programme] Big Brother housemates is probably not so different from how they form their impressions of politicians" (Campus 2013: 30-31). In the era of 'celebrity politicians', Campus (2013: 22 ) notes that "the personal factor can appear more appealing than all the other more abstract elements of politics", and perceptions of personal style and authenticity become important in voter evaluations as political ideology (Dahlgren 2009). In the business realm, McShane and Cunningham (2012) draw attention to the value of authenticity as a potentially valuable lens for enriching business ethics theorising. This is supported by Peus et al.'s (2012) call for further research looking at authenticity in relation to business leadership and Freeman and Auster's (2011: 15) recent attempt to "open up a line of research in business ethics on the concept of 'authenticity' as it can be applied in modern organizational life".

In exploring these issues, the research question addressed in this article is: how was Jeremy Corbyn constructed and evaluated as an authentic leader in the press? Building on previous membership categorisation analysis work on media materials (Eglin and Hester 1999; Stokoe and Attenborough 2015) and in organizational settings (Fairhurst 2007: Chapter 3), our analysis shows the ambiguity and ambivalence evident in how authentic leadership was discursively constructed in the media. The article concludes by considering the avenues that future research into media representations of the ethics of political and business leadership might productively take.

\section{Authentic Leadership}

The academic literature on authentic leadership explicates many problems in the enactment of authenticity but few regarding its desirability. Whilst a growing literature exists which is critical of the positive psychological underpinnings of the authentic leadership construct, there has been limited challenge to the notion that authenticity itself-in leadership as elsewhere-is a desirable characteristic. Harter (2002: 382) tells us that authenticity occurs when "one acts in accord with the true self, expressing oneself in ways that are consistent with inner thoughts and feelings". In relation 
to leadership, authentic leaders are said to be "transparent about their intentions and strive to maintain a seamless link between espoused values, behaviours and actions" (Luthans and Avolio 2003: 242). Deriving from normative and functionalist aims of delineating a style of leadership capable of producing measurable organisational outcomes (Avolio et al. 2004; Gardner and Schermerhorn 2004), authentic leadership has been defined as:

a pattern of leader behaviour that draws upon and promotes both positive psychological capacities and a positive ethical climate, to foster greater self-awareness, an internalised moral perspective, balanced processing of information, and relational transparency on the part of leaders working with followers, fostering positive self-development. (Walumbwa et al. 2008: 94) ${ }^{1}$

In line with the notion of authenticity as 'acting on one's values' or 'being true to oneself', authentic leadership was from an early stage coupled with issues of business ethics. Arising from the "ethical corporate meltdown" (May et al. 2003: 247) of scandals such as Enron and WorldCom, the development of the authentic leadership construct grew out of attempts to answer the question "what are the factors that influence ethical decision-making processes and behaviours of leaders ... and why [do] they choose to deceive their followers, shareholders and the general public?" (May et al. 2003: 247) Whilst the question of whether authentic leaders are always moral or ethical has received more critical attention recently (Algera and Lips-Wiesma 2012; Sendjaya et al. 2016), the importance of personal as well as professional morality by political and business leaders required to operate in the public eye (Grover and Hasel 2015) is readily apparent.

The notion of being 'true to oneself' has been highlighted by critical scholars as being, at best, a starting point for authenticity (Freeman and Auster 2011). This strand of the literature has challenged the focus of much theorizing in the field, seeing it as premature to seek to refine psychometric measures of authenticity and authentic leadership competences (see, e.g. Avolio and Gardner 2005; Gardner and Schermerhorn 2004: Walumbwa et al. 2008) before the philosophical underpinnings of the construct have been fully explored (Cooper et al. 2005). A significant psychoanalytic critique of authentic leadership has argued that "authentic

\footnotetext{
1 We are aware of a significant number of retractions (8 at last count) relating to articles authored by Walumbwa and colleagues. In most cases, the difficulties were methodological and the authors were unable to defend their position because the data had been destroyed (as stated on Retraction Watch). The 2008 article is not one of those that has been retracted, or had its methodological robustness queried, and remains a key article in defining the components of Authentic Leadership. We, therefore, feel it is appropriate to continue to cite it.
}

leadership as an indication of a leader's true self is impossible", and that the authentic leadership model "refuses to acknowledge the imperfections of individuals at the same time as privileging the collective (organisational) self over the individual self" (Ford and Harding 2011: 463). This latter aspect, where the organization exercises power through the expectations placed on the individual and the individual's efforts to conform to these expectations, introduced inauthenticity into everyday organizational life.

Similarly, embodying authentic leadership has been shown to be more problematic than merely expressing one's true self (Ladkin and Taylor 2010; Liu 2017). Scholars have pointed to the elements of dramatic performance (Goffman 1959) and "leaderly choices" (Ladkin and Taylor 2010: 64) as to what to reveal and what to conceal to suit the social expectations of different social settings. From an existential perspective, Lawler and Ashman (2012) reject authentic leadership's focus on an 'inner' or 'true' self in favour of the need to consider context and both subjective and intersubjective experience in the practice of authentic leadership. Summing up the critical concerns with authentic leadership, Costas and Taheri (2012) conclude that the positive psychology scholars' quest for change through the development of authentic leadership scales is likely to be a truncated, single-loop mission if the stress, anxiety, anger, pessimism and unhappiness of life and work are omitted from the equation. This significant, and nuanced, challenge to the early formulation of the authentic leadership construct has drawn attention away from its ethical underpinnings: an aspect of authentic leadership writing which this article brings back into the spotlight.

The rather technical configuration of authentic leadership which resulted from positive psychology also appears to be only loosely coupled with people's everyday experience of 'authentic' leaders or with any perceived linkage between authentic leadership and 'behavioural integrity' (Leroy et al. 2012). To date, little is known about how authenticity is constructed in naturally occurring discourse. Whether it is employees making sense of the business leaders they work with, or the electorate making sense of the political leaders they are voting for, most people have little knowledge of the technical definitions of authentic leadership found in the academic literature and the psychometric scales developed for this purpose (Walumbwa et al. 2008). However, the methods of reasoning about 'authentic leaders' in everyday discourse are significant because it is through this discourse that leaders are evaluated and judged in many settings, including business and politics. In the case of Jeremy Corbyn's leadership campaign, the discourse produced by the press was both constitutive of Corbyn's perceived leadership strengths and weaknesses (as the discourse constituted how people evaluated him as a candidate) and as a result consequential 
for his leadership career (as the discourse shaped how people made sense of his leadership abilities).

\section{New Labour and the 'Corbyn Phenomenon'}

Our article seeks to understand the so-called Corbyn phenomenon (Bale 2016; Richards 2016; Russell 2016; Ross and McTague 2017: 59-76; Shipman 2017: Ch. 22): the rise of Jeremy Corbyn from a rank outsider to the position of leader of the Labour Party. While many analyses have pointed to the appeal of his political ideas, our focus here is on his discursive construction in the media as an 'authentic leader'. The appeal of a more 'authentic' political leader first needs to be understood in the context of the broader history of British politics (Bale 2015; Thorpe 2015), and the 'politics of spin' more generally (Gould 2011; Grattan 1998), on the back of the New Labour project.

New Labour was established on 21 July 1994 when Tony Blair took control of the Labour Party after the premature death of John Smith. Blair then initiated a dramatic shift in both policy (bringing Labour towards the political centre ground) and practice (bringing in a new cadre of spin doctors, communications officers, opinion pollsters and focus groups) (Gould 2011; Rawnsley 2001). The three terms of Labour government that followed still attract widely divergent evaluations (Rawnsley 2010; Eaton 2017). For some, the Blair years represent an unprecedented electoral success that handed the party the opportunity to implement many of its policies, including Bank of England independence, the 'New Deal', the minimum wage, introduction of tax credits, the 'Good Friday Agreement' and real terms budget increases for the National Health Service (Gould 2011; Mandelson 2011). For others, in particular those on the 'hard left', the Blair victories are seen as a ballot box success that came at the price of compromising on core Labour values, especially with regard to labour rights and the alleviation of poverty and inequality (Seymour 2016).

The core assumption underlying 'Blairism' and New Labour was the notion that the proceeds of growth were a sufficient basis for increasing public spending, without having to significantly raise taxes on the wealthy and on corporations. This stance did not sit well with the 'hard left' of the party, whose basic principles were unqualified support for widespread (re)nationalisations, increasing taxes on high earners and corporations, substantial redistributive policies and a firm anti-EU stance. Even with its supporters, the viability and attractiveness of Blairism soon waned (Eaton 2017) and New Labour's landslide victory in 1997 turned into a disappointing $35.2 \%$ of the vote in 2005: just enough to remain in government. Only when Labour's ballot box success completely evaporated at the 2010 general election, was the New Labour project finally ended (Eaton
2017). Following a further comprehensive defeat in 2015 under Ed Miliband, the stage seemed set for Corbyn's rise. Viewed as someone with a different kind of appeal, "[h]e was decent, principled, unthreatening. He was authentically himself" (Ross and McTague 2017: 61).

During the final stage of the New Labour project, there was increasing reference to media spin and disillusionment with the increasing inauthenticity of politics. It is important to recognise, however, that this has international relevance and that the politics of 'spin' was by no means specific to the UK (Grattan 1998) or to any one party (Bale 2011; Street 2011: 10). In the UK, since the Blair years, public trust in politicians has remained low. The media has sought to highlight the inauthenticity of political figures from across the political spectrum, including Gordon Brown (Labour) ${ }^{2}$ (Guardian, 03/06/09) and David Cameron (Conservatives) ${ }^{3}$ (Observer, 25/04/15). The criticism of inauthentic politicians has been coupled with calls for more 'authentic' leaders and for leaders to be "individuals of good character" (Bragues 2008: 373). In this context, our aim here is therefore to investigate how Corbyn was discursively constructed and evaluated as an 'authentic leader' in the British press.

\section{Methodology}

The methodology employed in the study is grounded in an approach to studying talk and text known as membership categorisation analysis (Hester and Eglin 1997; Lepper 2000; Fitzgerald and Housley 2015). Antaki and Widdicombe (1998: 3) state that to have an identity-in this case as a leader- "is to be cast into a category with associated characteristics and features". Membership categories are the classifications or social types that may be used to describe a person: 'mother', 'pensioner', 'manager', 'leader' and so on. Category predicates are the sets of assumptions we have, and routinely use, about the sort of rights, responsibilities, expectations, obligations, knowledge, competencies, motives, activities and behaviours associated with these membership categories (Jayyusi 1984). In many situations, these category predicates are so deeply engrained and taken-for-granted that they do not need explaining or making plain but are merely 'common sense'. However,

\footnotetext{
${ }^{2}$ Brown was ridiculed for his 'fake smile', which was attributed to his spin doctors attempting to break down his dour and serious image: 'How do you crack a winning smile?' 6 May 2009. http://news.bbc. co.uk/2/hi/uk_news/magazine/8035540.stm.

${ }^{3}$ Cameron was equally ridiculed for failing to remember the name of his football team, despite claiming to be a fan: 'Watch incredible moment David Cameron FORGETS which football team he supports.' http://www.mirror.co.uk/sport/row-zed/cameron-west-hamaston-villa-5579303.
} 
in some situations, such as a political leadership contest, these predicates come to the fore and become an explicit part of the reasoning about various leadership candidates. In these situations, the qualities and attributes of leadership candidates will be evaluated according to these more or less shared and more or less consistent expectations about what a leader normatively should be like based on the category predicates associated with the role. In the case of political leaders, these anticipated qualities and attributes are tainted by the reporting of political scandals (Grover and Hasel 2015) and the widespread belief that politicians are people who "deny responsibility, hide information, and deceive others" rather than "lead[ing] with authenticity and integrity" (Peus et al. 2012: 331). The expected qualities-those we want to find in our political leaders-continue to conform to the normative category predicates, however.

The normative element of membership categorisation discourse is important because, as Widdicombe (1998) argues, category predicates furnish us with a rich set of inferential resources through which to interpret, judge and evaluate an individual and his or her actions according to the culturally shared set of assumptions about the 'type' of person they should be. According to Benwell and Stokoe (2006: 67), categories are "inference rich" because categorisation is a "normative practice through which inferences and implications are generated and managed" (2006: 66). People are not just allocated to a membership category, they are also normatively judged according to the generalised set of expectations associated with that category. This enables us to study how, in discourse, the "definitions, criteria or 'theory-in-use' through which leaders are evaluated" (Meindl 1995: 333) are constructed, challenged and maintained. Through analysing the discourse of leadership in an election campaign, it is therefore possible to map not only the discourse surrounding the individual leader but also the set of cultural expectations associated with the political leadership role itself. 'Type' is therefore related to 'role': there exists common-sense knowledge of the type of person best suited to performing a particular role. Membership categorisation analysis enables this 'bridging' between the individual (leader) and the category (the role and type associated with leadership) to be exposed and subjected to analytic scrutiny. In the present case, it highlights how evaluations were made through a set of implicit and explicit assumptions about the category predicates (Hester and Eglin 1997) associated with the leadership category and how these were utilised to construct understandings of leader authenticity.

In adopting a membership categorisation analysis approach, our analysis is located within a social constructionist paradigm. ${ }^{4}$ Specifically, it is concerned with the

\footnotetext{
${ }^{4}$ Notwithstanding the debate within the 'parent' discipline of ethnomethodology as to whether the label social constructionist can be applied to ethnomethodological and conversation analytic work (Ben-
}

social construction of leadership through the first-order discourse of members of a society (Fairhurst 2007, 2008). We focus on category predicates (Hester and Eglin 1997) relating to the rights, responsibilities, activities and expectations typically associated with categories. Working with written texts, membership categorisation analysis has been used to explore media texts relating to, for example, the 1989 Montreal Massacre (Eglin and Hester 1999), the allocation of blame in the reporting of criminal cases (Stetson 1999) and the 2011 bombings and mass shooting in Norway (Stokoe and Attenborough 2015).

Membership categorisation analysis is fairly novel in the field of leadership studies, with the exception of Fairhurst (2007: Chapter 3), Larsson and Lundholm (2013) and Whittle et al. (2015). Studying membership categorisation of leadership in the popular press is important because, as Alvesson and Sveningsson (2003) argue, the press provides the "scripts" (2003: 379) through which we make sense of leadership. The press not only reflects contemporary discourse of leadership, it is also involved in constituting that very discourse in a "reciprocal relationship" between the media and cultural understandings of leadership (Mavin et al. 2010: 556). In the case of authentic leadership, as Parry-Giles (2014) observes, the press position themselves as the ultimate judges of authenticity, identifying behaviours that fit with their portrait of an authentic leader, albeit often in contradictory and paradoxical ways.

As Watson (2015) argues, categories are not fixed and reified and members of a particular society are not "categorisation dopes" (Watson 2015: 30). Thus, categorisation needs to be studied as an "in situ, in vivo" phenomenon (Watson 2015: 29). We extend this argument by examining how the press make sense of whether a particular person (Corbyn) is, or could be, a member of a particular category (political leader). The question of how people who do not currently 'belong' to a category, but are seeking membership of that category, can be evaluated regarding their 'fit' is precisely the focus of the newspaper discourse we have analysed.

\section{Newspaper Coverage of Corbyn's Leadership Campaign}

The data set for this study was assembled based on a search of the Nexis newspaper data base using 'Corbyn' and 'leadership' as the search terms. The date range was set from 2 June 2015, when Corbyn announced he was standing in the Labour Party leadership election, to 13 September 2015, the day after he won the contest. Based on National Readership

Footnote 4 (continued)

well and Stokoe 2012; Eglin and Hester 2003; Hester and Francis 1997). 
Table 1 Readership of selected British newspapers

\begin{tabular}{lllrr}
\hline Newspaper (Sunday version) & Readership & Political stance & No. articles & $\begin{array}{l}\text { No. } \\
\text { pages of } \\
\text { text }\end{array}$ \\
\hline Guardian (Observer) & $793,000(711,000)$ & Left wing & 227 & 476 \\
Daily Telegraph (Sunday Telegraph) & $1,150,000(1,154,000)$ & Right wing & 76 & 114 \\
Times (Sunday Times) & $1,014,000(2,127,000)$ & Centre-right & 75 & 115 \\
Independent (Independent on Sunday) & $270,000(401,000)$ & Centre & 58 & 97 \\
Sun (Sun on Sunday) & $4,664,000(3,889,000)$ & Right wing & 39 & 42 \\
Daily Mail (Mail on Sunday) & $3,605,000(3,791,000)$ & Right wing & 23 & 30 \\
Totals & $11,496,000(12,073,000)$ & & 498 & 874 \\
\hline
\end{tabular}

Survey data ${ }^{5}$ from October 2014 to September 2015, the search included all major UK national newspapers as shown in Table 1. Table 1 also shows where each newspaper sits on the political spectrum, a factor which was sometimes relevant in how particular words or phrases were understood during our process of interpretation. The resultant data set is shown in the final two columns of Table 1.

\section{Data Analysis}

We started our data analysis with an a priori interest in the discourse of 'authentic leadership' and examined it using "an inductive "noticing"" (Stokoe and Attenborough 2015: 69) of where, and how, the press talked about Corbyn as an authentic leader. We were interested in the "publicly observable" (Stokoe and Attenborough 2015: 61) categorical reasoning of journalists and the commentators and sources they cited when reporting Corbyn's election campaign. The data were divided between the authors, and the entire data set was then subjected to a "careful reading and re-reading" (Rice and Ezzy 1999: 258) to arrive at a fine-grained understanding of the category predicates being deployed. We chose to exclude from the analysis any discussion of the policy domain, focusing only on discourse relating to Corbyn's personal leadership qualities (or lack thereof). The author team then shared their collections of category predicates (i.e. discourse about what a leader should be or be able to do) from which the three themes of consistent, principled and true-to-yourself were derived. It was during this stage of the analysis that the contrasting evaluations were first noted and later systematised into two collections: one portraying authenticity as a leadership strength and the other portraying it as a leadership weakness. This central finding is elaborated in the analysis below.

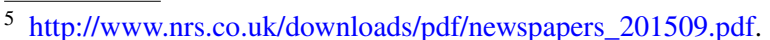

\section{Results}

This study identified three aspects of the construction of authenticity as a leadership strength in the media discourse we studied: consistency, being principled and being 'true to oneself'. Our analysis shows how as well as constructing these category predicates as positive leadership attributes, the press also negatively evaluated the same three category predicates in order to construct Corbyn as an ineffective leader. This suggests a fundamental ambivalence present in the discourse: at the same time as recognising the virtues and attractions of Corbyn's authenticity, the press also drew on those same attributes to undertake criticism of Corbyn's qualities as a leader. These three aspects of authenticity are now considered in turn.

Consistency The newspapers identified Corbyn's consistency in political position over time as an indicator of his authenticity. All the newspapers in this sample highlighted the stability of his position over a number of decades (since being elected in 1983): this was not someone who changed his position based on the current mood of the time or because his views were unpopular or hurt his 'electability'. The Guardian quoted a senior labour politician as saying:

[Corbyn] has not flipped: he has remained consistent. He has tapped into what people are saying and thinking. (31/07/15)

The Independent also highlighted consistency as a sign of Corbyn's authenticity:

... Mr Corbyn's authenticity may earn him grudging admiration from the sceptics. 'Jeremy does have one great merit, which he shares with the late John Smith: he has held broadly consistent views all his life,' Mullin said. (31/07/15)

The Sunday Times emphasised that campaigning for the hard left had "consumed Corbyn for most of his life" $(16 / 08 / 15)$ and quoted sources who stated that "Jeremy's got exactly the same views now as the day he got elected" $(16 / 08 / 15)$. Describing his election campaign material 
from 1983, The Sunday Times noted: “Corbyn's beard may have lost some of its lustre since then but his views have stayed exactly the same" (16/08/15). The Times described Corbyn as "a 66-year-old whose political views haven't altered since 1983" (04/09/15).

The term 'veteran' was used a total of 70 times across the seven newspapers in the data set. Specifically, it was used in such phrases as "veteran left-winger" or "veteran socialist" to signal the length of time Corbyn had been campaigning on leftist issues such as poverty, inequality and anti-war protests, signalling the consistency of his political position. Evidence of his consistency was also provided with reference to the number of times he had defied the 'party whip' - the official party line - and instead voted according to his own moral beliefs:

Corbyn, who opposed the decision to go to war in Iraq and has defied his party's whip 284 times since 2005, told The Guardian that his decision to stand came from a desire to present a view that differed from that of the other candidates. (Guardian, $12 / 06 / 15)$

However, at the same time, Corbyn was also criticised for his consistency and was regularly described as being "stuck in the past". He was characterised as representing the "troubled convention of ghosts from socialists past" (Independent on Sunday, 02/08/15), being there to "sing the old tunes" (Observer, 19/07/15), offering "old solutions to old problems" (Independent, 14/08/15), proposing "solutions which belong to the past" (Guardian, 14/08/15), failing to "evolve" (Sunday Times, 16/08/15), being uninterested in "refreshing or developing his views" (Sunday Times, 16/08/15) and failing to address "the challenges facing contemporary Britain" (Observer, 13/09/15). Corbyn was described as an "unreconstructed socialist" (Sun, 28/06/15), a "Marxist throwback" (Sun, 23/08/15), a "dinosaur" (Guardian, 08/07/15), a "1980s Trotskyist tribute act" (Guardian, 10/09/15) and "a dreary thinker whose new ideas were old even when he first had them 30 years ago" (Times, 04/09/15). Failing to adapt was positioned as a leadership weakness:

Some see Corbyn's unshakeable beliefs as a sign of his principles, but really they are indicative of a pedestrian thinker who lacks the ability or the originality to adapt to a changing world. (Sunday Times, $16 / 08 / 15)$

Corbyn was also characterised as becoming more dogmatic and embattled in his views over time, as ideals became "grudges":

Mr Corbyn's victory ... is a leap to the Left, back to the past. If Mr Corbyn's speech sounded well- rehearsed then it might be because it is a speech he has been giving ever since he entered Parliament in 1983. It is a speech full of old Left-wing ideas, nursed like grudges. (Sunday Telegraph, 13/09/15)

The press constructed the 'problem' associated with Corbyn's failure to adapt and change his views in terms of its impact on his party's electability:

Mr Corbyn, who was first elected in 1983, has views similar to those that were laid out in Labour's election manifesto that year, which provoked the Labour MP Gerald Kaufman ... to describe it as 'the longest suicide note in history’. (Independent, 11/09/15)

Corbyn was presented here as not offering credible leadership that could return the party to power but as being someone who would "take Labour back to the 1980s, when the party was doomed to the irrelevance of opposition" (Sunday Telegraph, 16/08/15).

Principled Corbyn was described in the media discourse as having principles that he held passionately, including being against British involvement in foreign wars and the Trident nuclear defence system, and for the nationalisation of public services, income redistribution and the opposition of austerity. One aspect of the principled discourse emphasised the strength of his beliefs and values. Corbyn was described as having "an all-consuming passion" (Sunday Times, 16/08/15), being a "left-wing firebrand" (Times, 06/07/15), having a "strong anti-austerity stance" (Independent, 16/07/15), and being "fiercely opposed to atomic weapons" (Independent on Sunday, 30/08/15). Corbyn's principled stance was also established through reference to his rejection of corrupting influences such as vested interests, corporate power or lobbyists. His campaign materials, cited in The Daily Telegraph, stated: "We have no big private donors" (17/08/15).

Corbyn was also portrayed using popular idioms and figures of speech associated with authenticity. For example, he was seen as epitomizing the idiom of "saying what you think'. The Observer described Corbyn as "the real deal" (02/08/15) and compared him with Farage, then leader of the anti-EU UKIP party, by saying "both share an easy authenticity: they are seen to say what they think" (Observer, 02/08/15). Corbyn was also characterised as someone who would enact his deeply held principles however unpopular or uncomfortable this may be, connecting to the idiom of 'practicing what you preach'. The Independent pointed out that Corbyn had made a career out of "championing unfashionable causes" (18/08/15), whilst for The Times, being principled meant being prepared to sacrifice one's own popularity for the values you believe in:

He champions the causes others won't reach out to. He was inviting Gerry Adams to parliament and observ- 
ing silences for dead IRA men in the 1980s. He campaigned for the release of Nelson Mandela when Margaret Thatcher was still calling him a terrorist. (Times, 18/07/15)

Being principled, then, meant being prepared to do something that attracts criticism and potentially damages your own career for the greater good. After his election victory, the Sunday Telegraph attributed his success to his steadfast commitment to his principles and never being afraid to speak up about them:

... he stuck to his guns and promised to fight for socialism. This steadfast commitment to his ideals is probably a big reason why he won. ... To his credit, he has never hidden what he believes in. (Sunday Telegraph, 13/09/15)

In contrast to this positive evaluation, Corbyn was also criticised for being "hostile to anyone who disagrees" (Independent, 11/09/15), a "dangerous ideological zealot" (Independent, 13/08/15), "extreme" (Sunday Telegraph, 13/09/15), an "obsessive political bore" (Times, 18/07/15), a "true torch-bearer of what was called the Loony Left" (Sun, 20/06/15), marred with "intellectual perversity and pomposity" (Telegraph, 18/08/15), and offering only "angry defiance" (Guardian, 18/08/15). In other words, while having principles was characterised as a strength insofar as it enabled Corbyn to be clearly categorised as an authentic leader, a parallel discourse positioned his strength of principles as a leadership weakness. Several papers (e.g. Sun, 24/07/15) focused on Corbyn's divorce from his second wife to perform criticism on his "excessive" adherence to principles, attributing the divorce to his dogmatic and uncompromising views against selective education and grammar schools.

A rhetorical contrast was constructed between 'principles' and 'pragmatics', ${ }^{6}$ with the former being viewed as impractical in the real world of politics and government. Discourse about the requirements of the 'role' of political leader was used to perform negative evaluations through this rhetorical contrast. Commentators pointed out that Corbyn's unshakable commitment to his values would fail to allow the practical compromises required for effective political leadership. Two key elements were present in this discourse: an 'electability' discourse concerning the pragmatism deemed necessary for winning a general election and an internal 'party leadership' discourse concerning the pragmatism deemed necessary for uniting a broad political party.

\footnotetext{
6 This rhetorical contrast device has been variously labelled by discourse analysts as the practical/principle rhetorical device (Wetherell et al. 1987) and the de jure/de facto device (Potter and Wetherell 1989).
}

The 'electability' discourse centred on the tension between the pursuit of 'purist' principles and the broad appeal deemed necessary for winning elections:

Devout Corbynistas say power is meaningless without principle, while centrists argue politics is pointless without seizing Number 10 [Downing Street, the Prime Minister's residence]. (Independent, 09/09/15)

Labour looks like a party rehashing a debate it had in the 1980s: to be a party of pure socialist principle or a party of government? (Observer 02/08/15)

Critics of Corbyn characterised him as a "protest politician" (Independent, 03/08/15), warning of the dangers of his leadership turning the Labour Party into a "party of permanent protest" (Times, 17/08/15). Contrasts were made between the kind of leadership needed to win elections and govern a country and what Corbyn's leadership was deemed to represent: a "chair of a discussion group" (Observer, 01/08/15) or a "protest movement [which] shouts from the sidelines" (Independent, 29/07/15). Here a discursive contrast is constructed between the kinds of attributes needed to be an "activist" (Wetherell and Potter 1992: 155) and those needed to lead an electable political party. Critics pointed to the "need for power to improve individuals' lives, rather than the opportunity to hold abstract principles" (Times, 17/08/15). According to this discourse, authenticity was indeed a virtue for the individual to hold, but not necessarily something suited to performing the role of being an effective political leader.

Others pointed to the problems, or even dangers, that Corbyn's principles would cause should he go on to become Prime Minister. The 'ideals' underpinning Corbyn's principles were contrasted to the kind of 'realism' needed to put principles into practice. Corbyn's critics characterised his views on social and economic policy as "starryeyed" (Guardian, 03/08/15), "woefully naïve" (Guardian, 25/08/15), based on "magical thinking" (Independent on Sunday, 02/08/15) only possible in fairy tales like "Alice in Wonderland" (Independent on Sunday, 30/08/15), and as "fantasy politics" (Times, 16/07/15) that could never be put into practice. Criticism of so-called Corbynomics for being "from a different planet" (Telegraph, 31/07/15) played on similar rhetorical contrasts between idealism and realism.

The internal "party leadership" discourse played out through another set of rhetorical contrasts. Corbyn's leadership effectiveness was questioned on the basis of his reputation for sticking to his principles and thus being unable to compromise:

Jeremy has made his reputation on the basis of not compromising. And that's fine for a certain role. But it isn't fine for the leader of the Labour Party. (Guardian, 14/08/15) 
Corbyn was portrayed as too dogmatic and purist to be able to unite the "big tent" (Guardian, 13/09/15) and "broad church" (Guardian, 17/06/15) of political views represented in the Labour Party. Those critical of Corbyn expressed concern that his strong principles would lead him to "impose" his views on the party (Telegraph, 15/08/15) and be unable to "deal with people who do not share his world view" (Independent, 26/08/15). Stark warnings were issued by critics that Labour would "tear itself apart" (Independent on Sunday, 02/08/15) and that Corbyn would "preside over some form of schism" (Independent, 10/08/15) and "civil war" (Sun, 24/07/15) in the party due to his inability to make compromises. ${ }^{7}$ Corbyn's unwavering commitment to his principles in defying the party whip also served in the discourse as evidence against him as an effective leader. Corbyn was accused of "serial disloyalty" (Mail, 05/08/15) and being a "defiant rebel" (Sun, 16/08/15). He was discursively positioned as a hypocrite and voters were asked to consider: how could someone who has defied his party's leadership so many times then seek to impose party discipline on others? Placing personal principles above party position in this way had, according to some, damaged his ability to lead the party:

Having cheerfully defied the whip 500 times, he would lack the authority - and perhaps the will - to hold Labour's patchwork tribe together. (Guardian, 18/08/15)

Between 1997 and 2010, Corbyn defied the whip 238 times. That's a lot of 'conscience'. It's also a very weak position from which to demand loyalty. (Guardian, 24/08/15)

True to himself The idea of being 'true to oneself' rather than succumbing to forms of social influence is central to everyday understandings and academic theories of authenticity alike (Goffee and Jones 2005). The media discourse in this study established their evaluation of Corbyn as 'true to himself' and 'honest' by constructing a contrast between Corbyn's leadership style and the culturally established 'type' associated with politicians. This 'type' discourse played on expectations of modern politicians as having PR advisers, using media soundbites, following a script, changing their policies according to opinion polls and focus groups. The Guardian wrote:

What's so interesting to me about Jeremy is that he is authentic at a time when people rightly value authen-

\footnotetext{
7 At the time of writing the Labour Party remains fractured although it has not officially split, with ongoing conflict between those in the centre-left associated with Blairism and those supporting Corbyn and the hard-left 'Momentum' movement that support him as leader. The term civil war is still being used to describe this conflict.
}

ticity over packaging, soundbites and slick PR which make up so much of modern politics. (23/07/15)

In physical appearance too, Corbyn's rivals were criticised for being everything he is not: the "embodiment of the welldressed, smooth-talking Westminster class" (Guardian, 18/08/15). The Independent described Corbyn as attractive precisely because he was "refreshingly outside the Westminster bubble" (09/09/15). It was also noted by The Independent that Corbyn had "no special advisers on hand" $(07 / 08 / 15)$ to advise him, and that in contrast to the evasive answers associated with politicians generally, Corbyn gave a "straight answer to a straight question" (07/08/15). Appearing not to be driven by PR advisers, soundbites and spin enabled the press to emphasise his honesty as a moral virtue:

He may not be able to match Podemos's Pablo Iglesias for charisma, but he's transparently honest and unspun. (Guardian, 06/08/15)

Corbyn was talked about as an "ordinary guy that people would like to talk to in the pub" (Guardian, 12/09/15), someone who "talks like a normal person" (Sun, 13/08/15), and a "straightforward and decent man" (Observer, 13/09/15). Being honest was portrayed as a leadership strength in appealing to an often weary and cynical electorate:

[Labour supporter]: 'A lot of young people have grown up in a Blair era of Americanised politics and spin. They respect the fact that Jeremy speaks his mind. He's unlike any other politicians.... He answers questions clearly, he doesn't depend on focus groups - he says what he thinks. ... Voters want someone who's more genuine, someone who's not just in it for themselves or lying to get elected.' (Observer, 03/08/15)

Even Corbyn's rivals for the Labour leadership acknowledged the appeal of his authenticity:

'Jeremy is representing a break with politics,' [Andy] Burnham says. 'There are no soundbites, there is no script. It is that which I think people are finding very attractive. The party is hungry for something different,' he goes on. 'It wants a bigger thing. It has been fed this diet of thin, meagre gruel of gimmicky policies. It is hungry. That is why it laps it up.' (Guardian, 03/08/15)

Corbyn's personal motives for seeking the leadership role were brought into the discourse as a further way of establishing his authenticity, again by noting the contrast with the 'typical' careerist politician. It is through this contrast that Corbyn's reluctance to put himself forward for leader was discussed, portraying him as seeking the leader role only to get his left-wing political principles and deeply held beliefs into the debate and onto the agenda, not to further his own career as a politician. The Independent noted that 
Corbyn only agreed to stand "after some insistence" from his supporters $(07 / 08 / 15)$, describing him as potentially entering "history's pageant of reluctant leaders" (07/08/15). He was portrayed as having no ulterior motive and as someone driven by principles over personal gain:

Frugal, self-effacing and an obsessive campaigner, veteran left-winger Jeremy Corbyn is a reluctant candidate for the Labour leadership. (Guardian, 24/07/15)

The newspapers also made much of how 'ordinary' Corbyn's habits and behaviours were in contrast to the ambitious and elitist Westminster political stereotype. He was described as "opting for a bicycle instead of a car" (Sun, 16/08/15) and "taking the night bus home from a rally, no chauffeur-driven car" (Guardian, 11/09/15).

In contrast to the positive evaluations of Corbyn's authenticity derived from his commitment to being 'true to himself', a more negative discourse was also present. This discourse was not explicitly critical but instead drew on cultural categories that are not traditionally associated with the category 'leader'. Here Corbyn's hobbies and appearance were both discussed. It was noticeable how the press highlighted the 'non-leader-like' hobbies that Corbyn engaged in, such as "tending his allotment in Islington" (Observer, 13/09/15), a hobby that is often culturally associated with retirement or with environmentalists. His other pastimes were also presented as 'strange' and not typically associated with 'leaderlike' activities:

Somehow there is room outside politics for Arsenal, the parliamentary cheese committee (the only blue thing he professes affection for is a ripe Stilton), woodturning (he makes bowls and chopping boards which he gives as gifts) and his allotment, which he still tends despite the demands of the leadership contest. (Times, 18/07/15)

There were also more explicitly negative evaluations of Corbyn's appearance, hobbies and age:

Centre stage is the crumpled character of Jeremy Corbyn, a pensioner happily pottering about his north London allotment who has suddenly discovered that his vintage leftism is strangely fashionable. (Independent, 03/08/15)

Corbyn's style of dress was identified as a contrast to the suited and clean-shaven appearance typically associated with politicians, with his beard targeted for particular attention. He was described as a "bearded socialist voter repellent" (Guardian, 19/07/15), a "bearded 66-year-old dressed in shades of muddy beige" (Guardian, 14/08/15) and "the grey-bearded man in the knitted fawn-coloured jumper" (Guardian, 11/09/15). Corbyn's style of dress was also untypical and un-leader-like: he dressed in "tatty old jackets"
(Observer, 13/09/15) and "shirts in non-committal shades of blah" (Guardian, 19/08/15), usually appearing "without a tie" (Observer, 13/09/15), but "with a little bit of vest poking out of the top" (Sun, 13/08/15) of his shirt and "a row of biros in his top pocket" (Observer, 11/08/15). The discourse highlighted the contrast between Corbyn's appearance and the typical or traditional appearance of a political leader:

Physically, he stands apart from his rivals - he is older and shabbier, face covered with a scrub of beard and shirt pocket rammed with an entire staffroom's worth of biros. (Guardian, 05/08/15)

This association with looking like a teacher rather than a politician was made explicit by some newspapers, who referred to "the state of his raggedy beard-which has always been more radical Seventies geography teacher than diehard Trot" (Times, 18/07/15) and described him as looking like "a shabby geography teacher in retirement" (Observer, 13/09/15). Being 'effective' was hereby associated with looking and sounding like a 'credible' politician.

\section{Discussion}

The central puzzle motivating this article was derived from the question of how it could be possible to represent a leader as authentic, and in particular morally principled, and also perform criticism of that leader on grounds of being ineffective. Our interest in this apparent anomaly stemmed from the fact that authentic leadership is celebrated in existing scholarship for its ethical foundation, thus making it surprising to see a supposedly 'authentic' leader being subjected to such fierce criticism by the media. The Labour Party leadership election, and the press's treatment of Jeremy Corbyn's leadership campaign, offers a rich example of this puzzle which enabled us to tease out how the contradictory discourses of ethics and effectiveness interacted. Our analysis showed that the very attributes or 'category predicates' the newspapers pointed to in order to identify Corbyn as an authentic leader-being consistent, principled and true to himself-were also drawn on in the discourse that sought to discredit him as an effective political leader. His authenticity became associated with "deviance, dogmatism and pathology" (Wetherell and Potter 1992: 164). 'Good' leadership was in turn associated with "flexibility, a practical attitude and openness" (Wetherell and Potter 1992: 164). This finding reveals the complexity of the authentic leadership discourse. Whilst being 'ethical' is presented as a positive component of the authenticity discourse relating to leadership, it is juxtaposed with another discourse about what makes a leader 'effective'. Being consistent, principled and true to self are presented as virtues, but virtues that are presented as standing in the way of the pragmatism, performance and 
credibility required of a leader. This juxtaposition illustrates how the ambivalence generated by the coexistence of ethics and effectiveness discourse was exploited by the press in order to undermine Corbyn's position as a prospective leader.

This finding contrasts with the predominantly positive framing of authenticity in the mainstream literature, which celebrates the inclusion of an 'ethical' component as part of authentic leadership and positions it unambiguously as a leadership virtue. Contrary to this positive theoretical positioning, authentic leadership was constructed in the media as an ambivalent phenomenon: at the same time as Corbyn was being heralded as a new type of authentic leader-one who stood by his principles even when this was personally difficult or potentially professionally damaging — he was also being discredited as a leader by evaluations of his incompetence and ineffectiveness in the leadership role. This finding is perhaps reflective of authentic leadership—and leadership more generally_as an "empty signifier" (Kelly 2014: 905): a physical absence which is ideologically filled to suit the needs of the time, with the press playing a significant role in how this is achieved. The tension between the discourses of 'ethics' and 'effectiveness' underpin the ambiguities and ambivalences in what the media tells us we want from our political leaders. The voting public might want both, but are told that they might need to compromise on the former in order to get the latter.

This analysis should not be seen as questioning or replacing a political science analysis of the "Corbyn phenomenon" (Bale 2016; Richards 2016; Russell 2016). Political science analyses would rightly emphasise the appeal of the radical left agenda in the face of widespread disenchantment amongst the British electorate, at a time of a prolonged regime of austerity and unprecedented economic and social inequality (Bale 2015; Thorpe 2015). Rather, our study seeks to complement this form of analysis by looking exclusively at the characteristics and attributes ascribed to the category 'political leader' in the ideological attack that has seemingly been directed at Corbyn by the establishment. Specifically, it builds on and advances Nyberg and Sveningsson (2014) analysis of the tensions and paradoxes leaders face when making sense of what it means to be 'authentic'. The respondents in their study noted that to be an effective leader they sometimes needed to be inauthentic. Our study has highlighted the tension between ethical characteristics-consistency, principles and being true to selfand what makes a 'good' leader. It is precisely this tension in leadership discourse-between being ethical and being effective- that is articulated in the attacks on Corbyn by the British press, adding further evidence to Nyberg and Sveningsson (2014) argument that there exists a "darker side" to the discourse of authenticity.
Others have put forward alternative theories of the apparent contradictions and paradoxes of authentic leadership. Goffee and Jones (2005) argue that the definition of authentic leadership can be refined to allow for the need to perform multiple roles in different contexts while still being 'true to yourself'. This formulation still rests on the problematic essentialist notion that there exists a 'true' and 'authentic' inner self, albeit one that manifests itself differently in different contexts. By developing Goffman's (1959) seminal insight, Ladkin and Taylor (2010) argue that authentic leaders have to strike a balance between displaying their "true self" and eschewing "acting" and "impression management", while at the same time avoiding the potential ineptitude of naïve honesty and transparency. It might be authentic to 'just be yourself', but real life requires that we 'put on a show' and 'perform' to expectations of our social, business - and in this case, political-roles if we are to be effective. The fact that Corbyn was ultimately successful in his leadership campaign, in part because he refused to conform to a disillusioned electorate's expectations of career politicians seeking their own advancement at the expense of their principles may be seen as a counter example here. In the newspapers representations in our study, Corbyn was berated for not striking an appropriate and effective balance, instead putting his principles firmly first. However, the idea that a deeply held and consistently enacted ethical position was not sustainable in the 'real world' of party leadershipand even less so in the requirements of a potential future prime ministerial role-was equally strongly present in the media discourse. We can therefore conclude that there exists ambiguity and complexity surrounding ideas of authenticity in leadership. Ibarra (2015) echoes this perception in proposing that a too rigid definition of authenticity risks getting in the way of what makes an effective leader, such as adapting to changing circumstances and being able to play different roles that require different selves to be displayed. So 'Corbyn the veteran campaigner' might need to down-play some of his ethical principles if 'Corbyn the party leader' is to unite his party and lead them to achieving real change in support of the principles he holds dear.

Our main contribution to this debate is to show how the press played out this tension between 'being authentic' and 'performing a role', in particular contrasting the ethical underpinnings of what it means to be authentic with the need to be effective in discharging the duties attaching to a leadership role. Our analysis has shown the discourses of political leadership that demanded that leaders should be authentic, but also media-savvy: able to make the compromises necessary in the real world, stay 'on message', stick to the 'party line', and appeal to heterogeneous audiences. Leaders were expected to be authentic, principled and true to themselves but also 'electable' by looking and behaving like a credible 
prime minister, with all the cultural stereotypes that entails (Parry-Giles 2014).

\section{Conclusion}

The current body of knowledge about how leadership ethics is represented has shown that discourse plays a fundamental role in how people make sense of what it means to be an 'ethical' leader. The recent spate of financial scandals and corporate misconduct cases, ranging from Enron in 2001 to the VW scandal in 2015, has left leadership studies with a renewed sense of urgency in redefining the purpose of leadership away from a singular focus on leader effectiveness and towards the inclusion of leader ethics. The media are important actors in this context because they both draw on, and contribute to, society's understanding of what a 'leader' should look like, should be and should do (Liu 2017). Ethics come into these media representations in three main ways. Firstly, the media can take a stance on what they consider to be morally appropriate behaviour (see, for example, Grover and Hasel 2015). Secondly, the media can also actively engage, or fail to engage, in discourse about the ethics of leaders following publicised instances of corporate wrongdoing (see, for example, Hannah and Zatzick 2008). Finally, the media have been known to celebrate the virtues of 'ethical' business leaders who place social and environmental responsibility at the heart of their businesses, such as the founder of The Body Shop (Pless 2007).

The findings of this study add another dimension to this body of work by highlighting the ambivalences and contradictions in the discourse of leadership ethics in ways that are more complex than 'black and white' understandings we have to date about 'bad' leaders (such as those involved in corporate wrong doing) and 'good' leaders (such as those known for their social or environmental activism). We advance this existing research by showing that leaders who are characterised as 'ethical' can also have their leadership credentials undermined through discursive devices suggesting that it is insufficient to be ethical as a leader if one is not also seen to be effective. By exploiting the discourse of leadership as a role-for example, as a role that requires someone who can be pragmatic and can compromise-the press questioned Corbyn's leadership capabilities and hence his effectiveness as a leader. While this process of discursive contestation might be more pronounced in political contexts, we propose that leadership in business can also be caught up in the ambivalence of the two competing discourses of ethics and effectiveness. For example, an 'authentic' business leader could also be discursively discredited if they are deemed unable to perform a leadership role that relies on making 'inauthentic' pragmatic compromises and enacting behaviours that require deviations from their own personal ethical position. We therefore propose that business leaders can experience the same tensions associated with the discourse of authentic leadership. As Grover and Hasel (2015: 191) observe, business leaders are "held in the public eye, even if that public eye is primarily their own organization".

\section{Limitations}

Our study is subject to some obvious limitations. It draws on UK press coverage of a single political leader over a relatively short period of time. Whilst it is not the aim of our approach to deliver generalizable results, we must nonetheless acknowledge the constraints this places on the scope of our findings. Similarly, whilst we postulate that business leaders operating in the increasingly public eye of the media are likely to face similar tensions between representations of ethicality and those of effectiveness, we have not explicitly shown this to be the case. On a practical level, the authors did not always find it straightforward to unravel ideology and policy related text from personal and role related text in their analysis, and their interpretation of the many overlaps is necessarily imperfect. Finally, as noted in the review of relevant literature, the authentic leadership construct itself is potentially problematic, with different perspectives on both its components and its feasibility in practice offering a complex and ambiguous platform upon which to build a sense of what it means to be authentic.

\section{Future Research}

We have proposed that the complex and contradictory discursive terrain of principled political leadership can also play out in business contexts where 'ethical' leaders are subjected to praise for their virtues but also criticism for their ineffectiveness. Future research could therefore be directed at studying how 'ethical' leaders in different settings can be subject to competing evaluations as their ethical values are discursively contrasted to the expectations about what it takes to be an 'effective' leader. Such research could consider leaders from across the broader political spectrum and business leaders from a range of sectors, as well as focusing more directly on media representations of ethics and ethical leadership. In doing so, there would be value in studies which flesh out the discourses surrounding the ethical component of authentic leadership and how this is represented in other forms of talk and text, including the texts found in practitioner publications and the talk collected in interview-based studies. The wider debate concerning the ethics of media representations of leadership and concerns surrounding the ideological processes underlying leadership discourses used in the media would likewise be worthy 
of study. Directions for future research could also include analysis of audience and reader reactions to the mainstream media, and could be extended to studying the discourse conducted within social media, an important aspect for furthering our understanding of the changing influence of different media sources in the modern age.

We are aware that our article draws on media material with a relatively narrow focus. The period covered by the texts in this study-drawn from the UK news media only-ended when Corbyn defied all predictions and won a landslide victory to become leader of the Labour Party in September 2015. Corbyn's leadership of the Labour Party was subsequently confirmed in September 2016 when he defeated a vote of no confidence passed by the Parliamentary Labour Party. Six months later, in June 2017, when Prime Minister Theresa May called a snap election, Corbyn and his party performed substantially better than anyone had expected, winning 262 seats and achieving the highest percentage of the vote share (40\%) since Tony Blair's landslide election victory in 1997. Many accounts have attempted to make sense of these dramatic events in British politics (e.g. Ross and McTague 2017; Shipman 2017), a number of which made favourable comparisons between Corbyn's perceived authenticity and consistency and Theresa May's often 'robotic' performances and unclear and changing value standpoints. To ground our results in a wider context, future research could usefully compare our findings with the press coverage of Corbyn in these later elections and once he was in post. Comparison of British coverage of Corbyn with international coverage, as well as with that of non-British leaders (President Trump would be an obvious example here) and leaders from the right of the political spectrum could also be expected to yield rich results.

\section{Practical Implications}

We began this article by highlighting the puzzle surrounding how an 'authentic leader', with all the positive moral connotations usually attached to this category in the existing literature and in naturally occurring discourse, could also be subject to persistent criticism. The media offers a unique context for understanding the social construction of authenticity in leadership and leaders, and in the political context especially our views of leaders are necessarily heavily influenced by television, newspapers and social media (Chen and Meindl 1991; Kuronen and Virtaharju 2013). But business leaders, too, are increasingly required to operate in the public eye and thus to balance representations of themselves and their activities as both ethical and effective. The current article has practical implications for how practicing leaders from all walks of life might choose to represent themselves and might seek to manage how they are represented by others.
At the same time, the insights developed in this article offer practicing leaders real world evidence of the importance of striking a balance between displaying their "true self" and eschewing "acting" and "impression management" (Ladkin and Taylor 2010) if they are to be judged as authentic, while still needing to avoid the perception of ineptitude arising from ascriptions of naïve honesty and transparency. The deep-rooted ethical considerations underpinning these representations should be ever-present in both the practice and theory of leadership.

Open Access This article is distributed under the terms of the Creative Commons Attribution 4.0 International License (http://creativeco mmons.org/licenses/by/4.0/), which permits unrestricted use, distribution, and reproduction in any medium, provided you give appropriate credit to the original author(s) and the source, provide a link to the Creative Commons license, and indicate if changes were made.

\section{References}

Algera, P. M., \& Lips-Wiesma, M. (2012). Radical authentic leadership: Co-creating the conditions under which all members of the organization can be authentic. The Leadership Quarterly, 23(1), $118-131$.

Alvesson, M., \& Sveningsson, S. (2003). The great disappearing act: Difficulties in doing 'leadership'. The Leadership Quarterly, 14(3), 359-381.

Antaki, C., \& Widdicombe, S. (Eds.). (1998). Identities in talk. London: SAGE

Avolio, B., \& Gardner, W. (2005). Authentic leadership development: Getting to the root of positive forms of leadership. The Leadership Quarterly, 16(3), 315-338.

Avolio, B. J., Gardner, W. L., Walumbwa, F. O., Luthans, F., \& May, D. R. (2004). Unlocking the mask: A look at the process by which authentic leaders impact follower attitudes and behaviours. The Leadership Quarterly, 15(6), 801-823.

Bale, T. (2011). The Conservative party: From Thatcher to Cameron. Cambridge: Polity Press.

Bale, T. (2015). Five year mission: The Labour Party under Ed Miliband (1st ed.). Oxford: Oxford University Press.

Bale, T. (2016). The loser takes it all. Labour and Jeremy Corbyn: A response to Steve Richards. The Political Quarterly, 87(1), 18-19.

Benwell, B., \& Stokoe, E. (2006). Discourse and Identity. Edinburgh: Edinburgh University Press.

Benwell, B., \& Stokoe, E. (2012). Discourse and identity. Edinburgh: Edinburgh University Press Ltd.

Bragues, G. (2008). The ancients against the moderns: Focusing on the character of corporate leaders. Journal of Business Ethics, 78(3), 373-387.

Campus, D. (2013). The media and representations of leadership. In D. Campus (Ed.), Women political leaders and the media (pp. 22-38). Basingstoke: Palgrave Macmillan.

Chen, C. C., \& Meindl, J. M. (1991). The construction of leadership images in the popular press: the case of Donald Burr and People Express. Administrative Science Quarterly, 36(4), 521-551.

Coleman, S. (2003). A tale of two houses. The House of Commons, the Big Brother House and the People at Home. Parliamentary Affairs, 53, 733-758.

Cooper, C. D., Scandura, T. A., \& Schriesheim, C. A. (2005). Looking forward but learning from our past: Potential challenges to 
developing authentic leadership theory and authentic leaders. The Leadership Quarterly, 16(3), 475-493.

Costas, J., \& Taheri, A. (2012). 'The return of the primal father' in Postmodernity? A Lacanian analysis of authentic leadership. Organization Studies, 33(9), 1195-1216.

Dahlgren, P. (2009). Media and political engagement: Citizens, communication, and democracy. Cambridge: Cambridge University Press.

Eaton, G. (2017). How the Labour left triumphed: The decade-long tale of how Jeremy Corbyn and his allies overcame repeated defeat and ridicule to win control of Labour and transform British politics. New Statesman. September, 23.

Eglin, P., \& Hester, S. (1999). Moral order and the Montreal massacre: A story of membership categorization analysis. In P. L. Jalbert (Ed.), Media studies: Ethnomethodological approaches (pp. 195-230). Lanham, MD: University Press of America.

Eglin, P., \& Hester, S. (2003). The Montreal massacre: A story of membership categorization analysis. Waterloo: Wilfrid Laurier University Press.

Fairhurst, G. T. (2007). Discursive leadership: In conversation with leadership psychology. London: SAGE.

Fairhurst, G. T. (2008). Discursive leadership: A communication alternative to leadership psychology. Management Communication Quarterly, 21(4), 510-521.

Fairhurst, G. T., \& Grant, D. (2010). The social construction of leadership: A sailing guide. Management Communication Quarterly, $24,171-210$

Fitzgerald, R., \& Housley, W. (Eds.). (2015). Advances in Membership Categorisation Analysis. London: SAGE

Ford, J. (2006). Discourses of leadership: Gender, identity and contradiction in a UK public sector organization. Leadership, 2(1), 77-99.

Ford, J., \& Harding, N. (2011). The impossibility of the 'true self' of authentic leadership. Leadership, 7(4), 463-479.

Freeman, R. E., \& Auster, E. R. (2011). Values, authenticity, and responsible leadership. Journal of Business Ethics, 98(1), I15-I23.

Gardner, W. L., \& Schermerhorn, J. R., Jr. (2004). Unleashing individual potential: Performance gains through positive organizational behaviour and authentic leadership. Organizational Dynamics, 33(3), 270-281.

Goffee, R., \& Jones, G. (2005). Managing authenticity. Harvard Business Review, 83(12), 85-94.

Goffman, E. (1959). The presentation of self in everyday life. New York: Anchor Books.

Gould, P. H. (2011). The unfinished revolution: How new labour changed British Politics forever. London: Abacus.

Grattan, M. (1998). The politics of spin. Australian Studies in Journalism, 7, 32-45.

Grover, S. L., \& Hasel, M. C. (2015). How leaders recover (or not) from publicised sex scandals. Journal of Business Ethics, 129(1), 177-194.

Hannah, D. R., \& Zatzick, C. D. (2008). An examination of leader portrayals in the U.S. business press following the landmark scandals of the early 21 st century. Journal of Business Ethics, 79, 361-377.

Harter, S. (2002). Authenticity. In C. R. Snyder \& S. J. Lopez (Eds.), Handbook of positive psychology (pp. 382-394). New York: Oxford University Press.

Hester, S., \& Eglin, P. (1997). Culture in action: Studies in membership categorisation analysis. Washington, DC: University Press of America.

Hester, S., \& Francis, D. (1997). Reality analysis in a classroom storytelling. British Journal of Sociology, 48(1), 95-112.

Ibarra, H. (2015). The authenticity paradox. Harvard Business Review, 93(1/2), 53-59.

Jayyusi, L. (1984). Categorization and the moral order. Boston: Routledge and Keegan Paul.
Kelly, S. (2014). Towards a negative ontology of leadership. Human Relations, 67(8), 905-922.

Kuronen, T., \& Virtaharju, J. (2013). The fishing president: Ritual in constructing leadership mythology. Leadership, 11(2), 186-212.

Ladkin, D., \& Taylor, S. (2010). Enacting the 'true self': Towards a theory of embodied authentic leadership. The Leadership Quarterly, 21, 64-74.

Larsson, M., \& Lundholm, S. E. (2013). Talking work in a bank: A study of organizing properties of leadership in work interactions. Human Relations, 66(8), 1101-1129.

Lawler, J., \& Ashman, I. (2012). Theorizing leadership authenticity: A Sartrean perspective. Leadership, 8(4), 327-344.

Lepper, G. (2000). Categories in text and talk: A practical introduction to categorization analysis. London: Sage.

Leroy, H., Palanski, M. E., \& Simons, T. (2012). Authentic leadership and behavioral integrity as drivers of follower commitment and performance. Journal of Business Ethics, 107(3), 255-264.

Liu, H. (2017). The masculinisation of ethical leadership dis/embodiment. Journal of Business Ethics, 144(2), 263-278.

Luthans, F., \& Avolio, B. J. (2003). Authentic leadership development. In K. S. Cameron, J. F. Dutton, \& R. E. Quinn (Eds.), Positive Organizational Scholarship: Foundations of a new discipline (pp. 241-258). San Francisco, CA: Berrett-Koelher.

Mandelson, P. (2011). The third man. London: Harper Press.

Mavin, S., Bryans, P., \& Cunningham, R. (2010). Fed up with Blaire's babes, Gordon's gals, Cameron's cuties, Nick's nymphets: challenging gendered media representations of women political leaders. Gender in Management: An International Journal, 25(7), 550-569.

May, D. R., Chan, A. Y. L., Hodges, T. D., \& Avolio, B. J. (2003). Developing the moral component of authentic leadership. Organizational Dynamics, 32(3), 247-260.

Mazzoleni, G., \& Shultz, W. (1999). Mediatization of politics: A Challenge for democracy? Political Communication, 16, 247-261.

McShane, L., \& Cunningham, P. (2012). To thine own self be true? Employees' judgments of the authenticity of their organization's corporate social responsibility program. Journal of Business Ethics, 108(1), 81-100.

Meindl, J. R. (1995). The romance of leadership as a follower-centric theory: A social constructionist approach. The Leadership Quarterly, 6(3), 329-341.

Nyberg, D., \& Sveningsson, S. (2014). Paradoxes of authentic leadership: Leader identity struggles. Leadership, 10(4), 437-455.

Parry-Giles, S. J. (2014). Hilary Clinton in the news. Gender and authenticity in American politics. Urbana: University of Illinois Press.

Peus, C., Weshe, J. S., Streicher, B., Braun, S., \& Frey, D. (2012). Authentic leadership: An empirical test of its antecedents, consequences, and mediating mechanisms. Journal of Business Ethics, 107(3), 331-348.

Pfeffer, J. (1977). The ambiguity of leadership. Academy of Management Review, 2, 104-112.

Pless, N. M. (2007). Understanding responsible leadership: Role identity and motivational drivers. Journal of Business Ethics, 74(4), 437-456.

Potter, J., \& Wetherell, M. (1989). Fragmented ideologies: Accounts of educational failure and positive discrimination. Text-Interdisciplinary Journal for the Study of Discourse, 9(2), 175-190.

Rawnsley, A. (2001). Servants of the people: The inside story of New Labour. London: Penguin Books.

Rawnsley, A. (2010). The end of the party. London: Penguin Books.

Rice, P. L., \& Ezzy, D. (1999). Qualitative research methods, a health focus. Melbourne: Oxford University Press.

Richards, S. (2016). Leadership, loyalty and the rise of Jeremy Corbyn. The Political Quarterly, 87(1), 12-17. 
Ross, T., \& McTague, T. (2017). Betting the house: The inside story of the 2017 election. London: Biteback Books.

Russell, M. (2016). Corbyn as an organisational phenomenon: A response to Steve Richards. The Political Quarterly, 87(1), 20-22.

Sendjaya, S., Pekerti, A., Härtel, C., Hirst, G., \& Butarbutar, I. (2016). Are authentic leaders always moral? The role of Machiavellianism in the relationship between authentic leadership and morality. Journal of Business Ethics, 133, 125-139.

Seymour, R. (2016). Corbyn: The strange rebirth of radical politics. London: Verso Books.

Shipman, T. (2017). Fall out: A Year of Political Mayhem. London: William Collins.

Stetson, J. (1999). Victim, offender and witness in the employment of news stories. In P. L. Jalbert (Ed.), Media studies: Ethnomethodological approaches (pp. 77-110). New York: University Press of America.

Stokoe, E., \& Attenborough, F. (2015). Category proffers and inferences in social interaction and rolling news media. In R. Fitzgerald \& W. Housley (Eds.), Advances in membership categorisation analysis (pp. 51-70). London: SAGE.

Street, J. (2011). Mass media, politics and democracy. Palgrave Macmillan.

Thorpe, A. (2015). A history of the British Labour Party (4th ed.). London: Palgrave Macmillan.
Walumbwa, F. O., Avolio, B. J., Gardner, W. L., Wernsing, T. S., \& Peterson, S. J. (2008). Authentic leadership: Development and validation of a theory-based measure. Journal of Management, 34(1), 89-126.

Watson, R. (2015). De-reifying categories. In R. Fitzgerald \& W. Housley (Eds.), Advances in membership categorisation analysis (pp. 23-50). London: SAGE.

Wetherell, M., \& Potter, J. (1992). Mapping the language of racism: Discourse and the legitimation of exploitation. Hemel Hempstead: Harvester Wheatsheaf.

Wetherell, M., Stiven, H., \& Potter, J. (1987). Unequal egalitarianism: A preliminary study of discourses concerning gender and employment opportunities. British Journal of Social Psychology, 26(1), 59-71.

Whittle, A., Housley, W., Gilchrist, A., Mueller, F., \& Lenney, P. (2015). Category predication work, discursive leadership and strategic sensemaking. Human Relations, 68(3), 377-407.

Widdicombe, S. (1998). 'But you don't class yourself': The interactional management of category membership and non-membership. In C. Antaki \& S. Widdicombe (Eds.), Identities in Talk (pp. 52-70). London: SAGE. 